DOI 10.15393/j10.art.2018.3721

\author{
Ирина Святославовна Андрианова \\ кандидат филологических наук, \\ заведующяая Web-лабораторией \\ Института филологии \\ Петрозаводского государственного университета \\ (Петрозаводск, Российская Федерация) \\ yarysheva@yandex.ru
}

\title{
Из редакционной переписки «Времени» и «Эпохи»: братья Достоевские, А. В. Зименко, И. А. Салов"
}

Аннотация. Письма - это тексты, в которых для читателя значим не столько эстетический, сколько познавательный аспект. Они нуждаются в критическом анализе и содержательном комментарии, установлении имен, датировок, раскрытии и интерпретации упомянутых в них событий. В статье анализируется письмо одного из корреспондентов Ф. М. Достоевского - А. В. Зименко. 19 декабря 1864 г. он обратился к писателю как редактору «Эпохи» с просьбой заплатить ему оставшуюся часть гонорара за повесть «Бутузка», вышедшую в журнале «Время» (1863, № 2 и 3). Достоевский вступил с ним в переписку. Однако настоящим автором «Бутузки» был писатель И. А. Салов. В статье приводятся архивные и мемуарные свидетельства, описывается служебная карьера А. В. Зименко в «Русском Вестнике» и других изданиях, воссоздается история знакомства и взаимоотношений А. В. Зименко и И. А. Салова. Обращение Зименко к Достоевскому в анализируемом письме следует рассматривать как просьбу посредника Салова. Нуждается в изучении вопрос, встречался ли сам Салов с Михаилом и Федором Достоевскими. Переписка Достоевских и Зименко раскрывает практику редакционной работы в журналах «Время» и «Эпоха», позволяет выяснить некоторые обстоятельства публикации сочинения Салова «Бутузка» и роль в этом процессе его друга и посредника Зименко - одаренного поэта, секретаря нескольких известных периодических изданий, правую руку М. Н. Каткова в 1856-1858, 1861-1863 гг.

Ключевые слова: Ф. М. Достоевский, А. В. Зименко, И. А. Салов, П. В. Быков, «Бутузка», «Русский Вестник», «Время», «Эпоха», М. М. Достоевский, научный комментарий

И

стория публикации и изучения переписки Ф. М. Достоевского длится уже сто тридцать пять лет. Она началась в 1883 г., когда усилиями вдовы писателя был выпущен первый том его посмертного Полного собрания сочинений, в состав которого вошли 147 писем самого Достоевского. С тех пор исследователи осознали важность публикации не только писем Достоевского, но и его корреспондентов: «...эпистолярные свидетельства современников <...> обогащают биографию писателя новыми фактическими данными», «воссоздают ту общественную и психологическую атмосферу, в которой проходили его жизнь и деятельность» [Ланский: 349].

Сегодня многие из писем корреспондентов Достоевского уже опубликованы в печатном и электронном виде. Однако письма - это тексты, в которых для читателя значим не столько эстетический, сколько познавательный аспект. Поэтому после первой публикации эти исторические документы эпохи нуждаются в критическом анализе и содержательном комментарии,

() И. С. Андрианова, 2018 
установлении имен, датировок, раскрытии и интерпретации упомянутых в них событий, связывании их содержания с реальной действительностью. Такая работа комментатора будет носить исследовательский характер, в ее основе - поиск информации в архивах, справочных изданиях и периодике XIX в. При этом важно среди найденных источников отделить подлинные документы от мистификаций. Иногда исследователь, не обнаружив прямых доказательств своих версий и ориентируясь на косвенные, выступает интерпретатором событий, изложенных в письмах.

Среди корреспонденции Достоевского 1864-1865 гг. сохранились четыре письма от А. В. Зименко, которые полностью были опубликованы только недавно (электронная публикация в рамках проекта Петрозаводского государственного университета) ${ }^{1}$. После прочтения уже первого из них у внимательного исследователя неизбежно возникают вопросы, для ответа на которые требуется поиск биографических сведений об авторе писем, его деятельности, окружении, обнаружение архивных свидетельств, раскрывающих реакцию Достоевского на эти письма. Такие сведения оказали бы помощь в прояснении двух загадок: кто такой Ардалион Зименко и какова его цель обращения к писателю?

19 декабря 1864 г. Ардалион Васильевич Зименко отправил письмо к Ф. М. Достоевскому как к ответственному редактору журнала «Эпоха», взявшему на себя эти обязанности после смерти брата Михаила². Обращение к Достоевскому не по имени-отчеству, а по форме «Милостивый Государь Г. Редакторъ» подразумевает дистанцию между автором письма и адресатом, подчеркивает неналаженность их личных и деловых отношений и придает письму официальный характер. Корреспондент писателя желает получить оставшуюся часть гонорара за «повесть» «Бутузка», напечатанную во 2-м и 3-м номерах журнала «Время» за 1863 г. В подтверждение долга редакции перед ним он цитирует «съ буквальною точностію» письмо старшего брата писателя (приводится нами ниже) и обещает по требованию редакции предоставить его подлинник:

$$
\text { «С. П. Б. } 15 \text { мая, } 1864 \text { г. }
$$

М<илостивьй $>\Gamma<$ осударь> Ардал<іонъ> Васил<ьевичь>. Множество обстоятельстьь частію непредвидннныхь, не позволили мнг выслать Валь деньги къ назначенному сроку. Вь этомь мюсяип у меня были большіе платежи, и я боялся, что у меня не достанеть денегь, еслибъ я Вамь выслаль ихь раньше. Извините сдплайте одолженіе. А потомь, я пробыль нпкоторое время въ Москвп и хотпль завести Вамь деньги лично, но право забыль Вашь адрест, а узнать бьло негдю.

Посьлаю Вамъ, что могу. Такъ какъ я вынужденъ обстоятельствами, нисколько оть меня независящцими, издавать журналь по 6 р. влиьсто 16, то Вьь можете себп представить, что я самь очень нуждаюсь. Если буду въ состояніи, 
то остальныя деньги уплачу черезъ мпосяцьь, если жъ нютъ, то подождите до января. Прошу Васъ. Заплачу съ процентами.

Ньньче утром⿰ я отправиль къ Вамь вь страховомь письми переводь на Юнкера въ 250 р. сер.

Примите увтьреніе въ совершенной готовности къ услугаль Вашего слуги

M. Достоевскій».

«Повесть» «Бутузка», гонорар за которую просил Зименко, действительно вышла во 2-м и 3-м номерах журнала «Время» за 1863 год (с. 201-271 и 235-321 соответственно). Произведение проникнуто пафосом осуждения недавнего крепостнического прошлого. В центре повествования избалованная собака Бутузка и ее хозяйка, деспотичная помещица Аксинья Максимовна:

«Привязанность ея къ Бутузкъ доходила даже до того, что она требовала отъ прислуги, чтобы та вставала, когда проходила Бутузка. И Бутузка такъ понимала это, что всегда оскаливала зубы и всегда ощетинивалась, когда прислуга не исполняла этого приказанія. Если же посль этого она не вставала, то Бутузка принималась визжать, лаять и бросаться на всъхъ; на этотъ визгъ прибъгала разумъется Аксинья Максимовна, и по своему уже расправлялась съ непослушными» (Время. 1863. № 2. С. 208).

За непочтение к ее любимице помещица засекала людей до полусмерти, отправляла в солдаты, ссылала на каторгу, а своего племянника Алешу Крутоярова за отчаянную попытку утопить приносящую несчастья Бутузку лишила своей милости и наследства.

Проблема, однако, в том, что автором этого произведения в журнале значится не Зименко, а Илья Александрович Салов (1834-1902) - прозаик и драматург, один из представителей демократического направления в русской литературе второй половины XIX в. Авторство Салова подтверждается его признанием в мемуарах: «В это время я написал одну только повесть "Бутузка", которая была напечатана в журнале М. М. Достоевского “Время"»4. Художественный текст, названный Саловым и Зименко «повестью», при публикации получил жанровое определение «романа в двух частях», хотя, по мнению исследователей, «производит впечатление растянутого рассказа (жанра более привычного для Салова)» [Краснов: 462] (см. также: [Себелева: 39]). «Бутузка», «своеобразный перевертыш» «Муму» [Краснов: 462], была создана «не без прямого влияния» Тургенева «и, вместе с тем, в полемике» с ним [Самочатова: 100]. Творческая манера Салова рождалась не только под воздействием И. С. Тургенева, но и М. Е. Салтыкова-Щедрина, а его повести и рассказы печатались в известных журналах того времени - «Русском Вестнике», «Отечественных Записках», «Современнике», «Русской Мысли». Произведения Салова, отразившие расслоение крестьянской общины и появление кулаков в русской деревне, - получили высокую оценку 
современной ему критики. «Один из самых талантливых беллетристов нашего времени», - так характеризовал И. А. Салова критик и историк литературы А. М. Скабичевский [Скабичевский: 347]. Литературовед и этнограф А. Н. Пыпин отмечал, что «некоторые из его деревенских героев могут считаться в ряду лучших народных типов, какие есть в нашей литературе» [Пыпин: 882]. Тем не менее писатель не стал крупной фигурой русской литературы второй половины XIX в. - к изучению его творчества обращались литературоведы (см., напр.: [Хованский: 162-166], [Ден], [Смирнов], [Рожков], [Никонова], [Кохно], [Краснов], [Себелева]), но имя его практически неизвестно современному читателю.

Почему же в письме к Достоевскому Зименко требует деньги за чужое произведение как за свое личное, ни разу не назвав имени настоящего автора: «...я согласенъ подождать уплату», «...приготовиль мнюь должныя имъ деньги», "...объясненіе о моихъ счетахъ съ покойнымъ редакторомъ», «...сколько слюдуеть мнп», «...должныхъ мнп редакціей журнала Эпоха денегъ» (выделено мной. - И. А.)? Более того, точно так же, как и Михаил Михайлович в процитированном Зименко письме, Федор Михайлович, не удивляясь, ведет с ним по этому вопросу переписку. Ответных писем Достоевского не сохранилось. Однако о том, что они были, свидетельствуют не только письма Зименко от 1 февраля, 23 марта, 17 мая 1865 г., но и наброски планов писателя в его рабочей тетради 1864-1865 гг.:

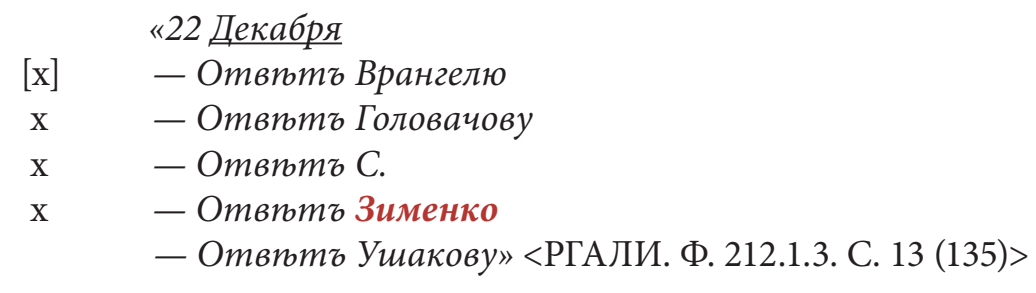

«2

$\begin{array}{ll}\mathrm{x} & \text { Тургеневу } \\ \mathrm{x} & \text { Зименко } \\ & - \text { Врангелю } \\ & - \text { Шидловскому» <РГАЛИ. Ф. 212.1.3. С. } 15 \text { (133)> }\end{array}$

Эти записи были сделаны Достоевским в перевернутом положении тетради и велись с ее конца. Крестики, поставленные слева от некоторых пунктов плана, свидетельствуют об их выполнении - исходя из этого, ответные письма Зименко Достоевским были написаны 22 декабря и 2 февраля 1865 г. В этой же тетради размещен адрес Зименко, перенесенный из его письма от 19 декабря 1864 г. и повторенный в письмах от 1 февраля и 23 марта 1865 г.:

«Зименко въ Москву, его В<ысокоро>дію Николаю Павловичу Горбунову,

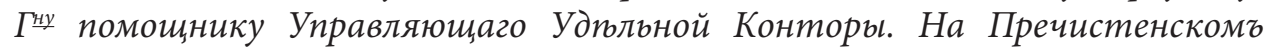


бульварп, въ домп Удюльной Конторь съ передачею Ардальону Васильевичу Зименко.»<РГАЛИ. Ф. 212.1.3. Л. 18 (131) $>^{5}$

Рабочая тетрадь 1864-1865 гг. с упомянутыми выше записями была впервые опубликована в 83-м томе «Литературного наследства» с комментариями К. Н. Полонской и С. С. Борщевского ${ }^{6}$. Однако записи с фамилией Зименко остались без какого-либо пояснения. В дальнейшем, в 1985 г., вышла публикация Т. И. Орнатской с записями адресов знакомых Достоевского из его записных книжек и тетрадей. Здесь приводится московский адрес Зименко из тетради 1864-1865 гг. и дан краткий комментарий, свидетельствующий, что исследовательница не увидела просьбу о гонораре за чужое произведение: «Адрес писателя А. В. Зименко записан после получения письма от него от 19 декабря 1861 г. (Ошибка! Нужно: 1964. - И. А.), где содержалась просьба выплатить долг за повесть, напечатанную еще в журнале "Время"» [Орнатская: 19]. Только комментаторы ПСС впервые обратили внимание на то, что Зименко вступил в переписку с писателем «в связи с пересланным им для “Времени” романом (“повестью”) И. А. Салова “Бутузка"».

Если Зименко не автор «Бутузки», то кто он - ловкий мистификатор, решивший обмануть Достоевского и нажиться на чужом произведении, или посредник между И. А. Саловым и редакцией?

Имя А. В. Зименко сегодня совершенно забыто. В письмах к Достоевскому от 1 февраля и 23 марта 1865 г. он предлагает редактору «Эпохи» для публикации свою повесть «Маскарад, случай из современной московской жизни» и услуги в качестве обозревателя интересных событий Москвы. Из этого можно сделать вывод, что он являлся литератором. Но в биографических словарях писателей ${ }^{8}$ в том числе в тех, где описано окружение Достоевского 9 , нет никакой информации об этом лице. Осуществляя републикацию пофамильного списка поэтов, писавших для журнала «Пантеон», составленный автором «Современника» ${ }^{10}$, создатели «Некрасовского сборника» даже не смогли установить его имя и отчество, обозначив в «Указателе имен»: «Зименко (поэт)»"11. Впрочем, в «Журнале Министерства Народного Просвещения» за 1848 г. приводится «полный перечень» поэтов, «наполнявших в разных журналах отделы стихотворений», и среди них отмечен Ардалион Зименко ${ }^{12}$. Обнаруженные нами его многочисленные стихотворения в журналах «Иллюстрация» за 1847 и 1848 г. («Любовь», «Сонет», «Дорога», «Дума» и др.) и «Пантеон и репертуар русской сцены» за 1850-1851 гг. («Тучи», «Мой друг! Когда твои прекрасные глаза», «Молитва», «Ночь» и др.) свидетельствуют о том, что А. В. Зименко был по преимуществу поэтом, и поэтом, не лишенным дарования ${ }^{13}$. Не случайно князь Г. В. Кугушев выбрал его стихотворение «Скажите мне, зачем порою» для создания романса (1856) [Фойницкий: 196]. Долгое время считалось, что слова для знаменитого романса композитора П. П. Булахова «Нет, не люблю я вас» 
также были написаны Зименко - это сообщил сам композитор и это отражено во всех нотных изданиях до 2002 г. При этом инициалы предполагаемого автора стихов никто до сих пор установить не мог - то ли «А. В., то ли П. А.» [Эльзон, 2002: 251-252]. Авторство текста было установлено М. Д. Эльзоном - это стихотворение Владимира Соллогуба, написанное около 1855 г. в альбом юной родственнице княгине Юлии Сергеевне Голицыной. От Зименко же, по предположению исследователя, Булахов услышал стихотворение и потому подписал текст его именем [Эльзон, 2002: 251-252].

\section{НЕТ, НЕ АЮБАЮ Я ВАС}

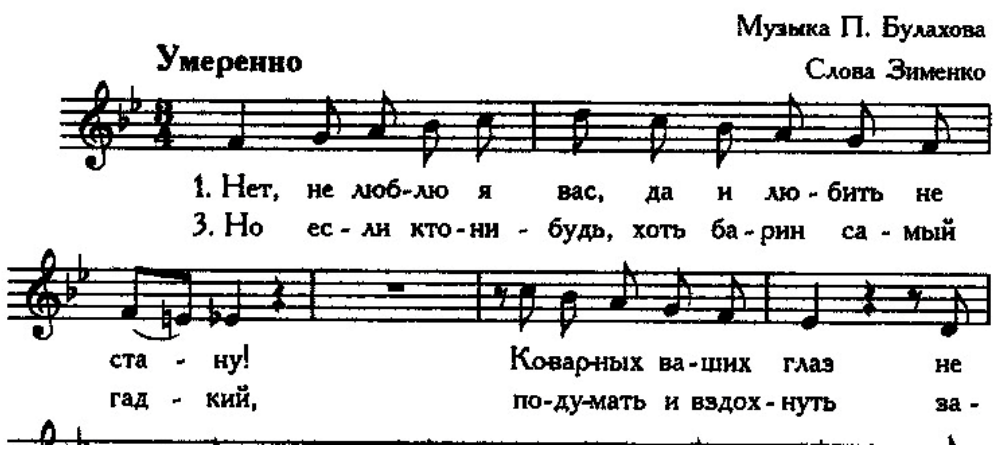

Илл. 1. Фрагмент нотного издания

Во всяком случае во второй половине XIX в. Зименко был известен в литературных кругах. Не случайно он является одним из персонажей фельетона «Опыт словаря псевдонимов современной русской литературы», вышедшего в сатирическом журнале «Искра» за подписью «Псевдоним»: «Многие, впрочем, уверяют, что М. Катков есть не иное что, как псевдоним, под коим скрывается г. Зименко, известный под мнимым званием "Секретаря редакции Русского Вестника”» ${ }^{14}$. Фельетон выдержан в юмористическом ключе: Зименко не писал под фамилией Каткова. Однако он действительно являлся его сотрудником - секретарем журнала «Русский Вестник» и газеты «Московские Ведомости» - и «восторженным почитателем», за что был прозван «Катковщиной»

Вся служебная деятельность Зименко представлена в «Докладной записке» в Литературный фонд от 13 апреля 1892 г., написанной его рукой и хранящейся в РО ИРЛИ (Отд. пост. № 14239). Провинциальный домашний учитель Ардалион Васильевич Зименко в феврале 1856 г. был приглашен на должность секретаря «Русского Вестника» М. Н. Катковым. Через три года по приглашению А. Д. Желтухина, предпринявшего издание «Журнала для землевладельцев», Зименко перешел туда на секретарскую должность, где прослужил до закрытия журнала в апреле 1860 г. Далее короткий период 
он был секретарем газеты «Русские Ведомости», а в 1861 г. вернулся к Каткову в «Русский Вестник» и «Московские Ведомости», исполняя секретарские обязанности более двух лет. Воспоминания Зименко о непростом начале работы арендованных Катковым Университетской типографии и газеты «Московские Ведомости» в конце 1862-го - начале 1863 года были опубликованы в журнале «Русский Архив» ${ }^{16}$ (см. также об издательской работе М. Н. Каткова: [Перевалова]). В 1866 г. Зименко поступил на службу в Правление Общества поземельного кредита в Санкт-Петербурге, где прослужил 23 года до октября 1889 г. Находясь в бедственном положении, он обратился в Литературный фонд с просьбой о ссуде и предоставлении ему «занятий, которые хоть сколько-нибудь облегчили бы существование его семье, состоящей из жены и малолетнего сына» ${ }^{17}$.

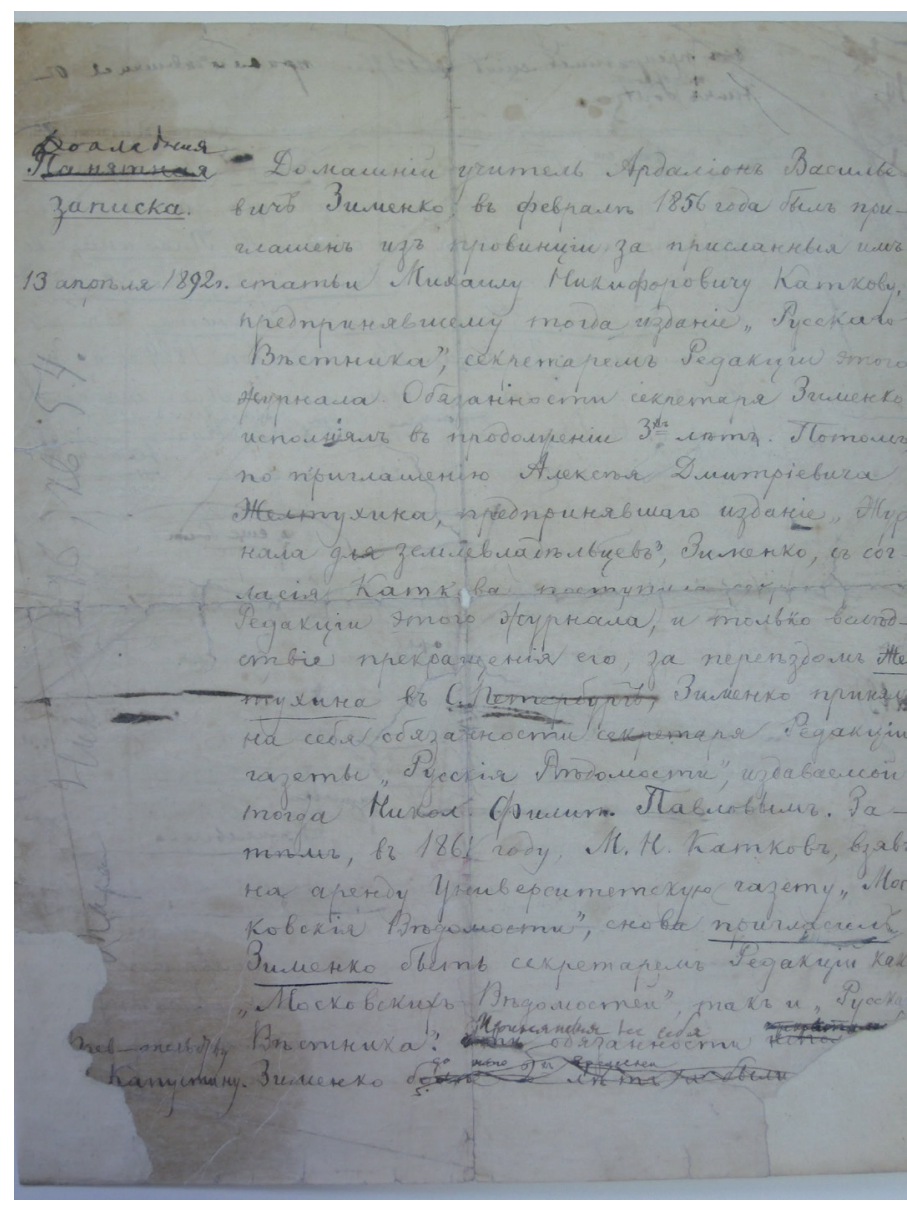

Илл. 2. Фрагмент докладной записки А. В. Зименко (РО ИРЛИ. Отд. пост. № 14239) 
Именно в редакции журнала Каткова «Русский Вестник» состоялось знакомство А. В. Зименко и И. А. Салова. Последний дебютировал на литературном поприще произведениями, опубликованными в этом журнале: в 1858 г. здесь вышла его повесть «Пушиловский регент» (Т. 13. С. 349-394), а затем рассказ «Забытая усадьба» (Т. 14. С. 132-148). «Все хотелось что-нибудь написать такое, что бы можно было поместить в толстый журнал. <...> И вот вдруг, словно на мое счастье, возник в Москве новый журнал, Русский Вестник, под редакцией Каткова. Журнал этот сразу стал на твердую почву и приобрел массу подписчиков», - вспоминал Салов ${ }^{18}$. Первая часть его мемуаров была напечатана еще при жизни автора - в 1897 г. в журнале «Русская Мысль», вторая - посмертно, будучи приобретена редакцией «Исторического Вестника» у наследников писателя ${ }^{19}$. Именно воспоминания Салова проливают свет на историю его знакомства и дальнейших взаимоотношений с Зименко:

«...на крыльцо вышел какой-то молодой человек с толстой папиросой в зубах. Увидав меня, он спросил:

- Вам кого угодно?

- Михаила Никифоровича, - ответил я робко.

- Его дома нет, но, ежели вы имеете какое-нибудь дело до редакции, так я секретарь редакции, - и затем, подавая мне руку, прибавил: - Ардальон Васильевич Зименко.

Я познакомился с ним и, скрепя сердце, передал ему рассказ: Пушиловский регент.

- Вы хотите поместить его в Русский Вестник? - спросил Зименко.

- Хотелось бы, — ответил я, опуская глаза.

- Хорошо-с, я передам его Михаилу Никифоровичу. А вы понаведайтесь недельки через две. <...> Я всегда сижу в редакции, а потому и обратитесь прямо ко мне» ${ }^{20}$.

После выхода в 1863 г. «Бутузки» в журнале братьев Достоевских литературная деятельность Салова прервалась на 13 лет, что было связано с изменением в начале 1860-х его семейного, материального и служебного положений. Женившись в ноябре 1861 г., он на два года уехал за границу, а затем уже навсегда поселился в Саратовской губернии. Здесь выходец из семьи разорившихся дворян получил неожиданное наследство - имение Ивановка, был избран мировым судьей, «каковым и прослужил со дня открытия мировых судебных учреждения в Саратовской губернии до дня закрытия таковых $»^{21}$. Но именно Зименко, у которого с Саловым установились дружеские взаимоотношения, стал инициатором возвращения последнего в 1870 -е гг. в литературу (к тому времени Салов уже остался вдовцом «с двумя детьми на руках»). «Очень может быть, - вспоминал Салов, - что, занявшись службой и хозяйством, я и совсем бы забыл про литературу, если бы както летом не приехал ко мне Зименко, секретарь редакции “Русского Вестника". Он 
прогостил у меня недели две и положительно не давал мне покоя, настаивая, чтобы я непременно что-нибудь написал и посвятил ему. Вот тогда-то я и написал рассказ “Мельница купца Чесалкина”. Рассказ этот не вымысел, и все действующие в нем лица были взяты с натуры» ${ }^{22}$. В «Мельнице купца Чесалкина» представлен выразительный образ сельского кулака-стяжателя, богомольность которого не мешала ему всячески обманывать простых мужиков. Рассказ был опубликован у Салтыкова-Щедрина в «Отечественных Записках» (1877. Т. 234. № 9) и подписан «Н. Салов» (так автор указан и в оглавлении) - псевдоним ли это писателя или ошибка наборщика, прочитавшего вместо письменной буквы «И» - «Н», достоверно неизвестно ${ }^{23}$. Автор выполнил обещание, данное Зименко, и посвятил свое первое после многолетнего перерыва произведение ему.

\title{
MEЛ⿱一𫝀口十工IITA
}

КУПЦА ЧЕСАЛКИНА.

(Посващается А. В. Зщменко).

\begin{abstract}
Сдучалось ли вамъ когда·нибудь ловить или, по мъстному выраженію, бить рыбу острого̆? Если не случалось, то я разскажу кақъ әто дълается. Острога̀ есть нъ̆тто въ родъ небольпихъ жельзныхъ вилъ, на зубьяхъ которнхъ устраиваются бородки, какія дылаются на удочкахъ, чтобы рыба не соскакивала. Острога̀ имьетъ трп-qетыре такіе зуба, смотря по величи-
\end{abstract}

Илл. 3. Фрагмент из журнала «Отечественные Записки»

Отметив эти свидетельства дружеских взаимоотношений Салова и Зименко, попытаемся разобраться в причинах обращения последнего к Достоевскому за оставшейся частью гонорара за опубликованное сочинение «Бутузка». В «Летописи жизни и творчества Достоевского» Зименко назван посредником Салова ${ }^{24}$, что косвенно подтверждается описанными в нашем исследовании архивными и мемуарными свидетельствами. Такие формы взаимодействия редакции и автора были обычной практикой во «Времени» и «Эпохе» и зафиксированы в приходно-расходном журнале: «За повпсть Ю. В. Жадовской во второмъ нумерп “Времени” получиль для передачи авмору Шилль», "Получиль для передачи г-жю Евгеніи Турь двюсти руб. 00. А. Лохвиикій», "Для передачи Барсову пол<училь> Тибленъ» и др. ${ }^{25}$ По всей вероятности, подобным же образом Салов, получив неожиданное и крупное наследство (2 тыс. десятин земли) и отправляясь в двухгодичное свадебное 
путешествие за границу весной 1862 г., передал дело по изданию своего сочинения комиссионеру Зименко. Самостоятельное общение с редакцией в условиях пребывания вне России было бы затруднительно для автора «Бутузки», а с Зименко он находился в дружеских отношениях и полагался на его литературные связи. Когда писатель передал рукопись посреднику до отправления в Европу или во время пребывания за границей - неизвестно. Комиссионер Зименко взял на себя заботу о гонораре Салова после смерти издателя «Времени». Получил ли Зименко деньги - неизвестно. Наше обращение к приходно-расходным книгам «Времени» и «Эпохи» (НИОР РГБ. Ф. 93.І.3.21, 93.І.3.22) и записям денежных расчетов по изданию журналов (НИОР РГБ. Ф. 93.І.3.23) никакой информации не дало: записи о выплатах Салову и / или Зименко отсутствуют. Не зафиксирована в них и выплата первой части гонорара - отправленные М. М. Достоевским 250 рублей в Москву на банкирскую контору Юнкера.

В объемных и очень подробных воспоминаниях Салова рассказывается о кратковременных встречах и длительном общении мемуариста со многими людьми из литературного круга. Здесь мастерски изображены портреты М. Е. Салтыкова-Щедрина, А. Н. Островского, И. И. Лажечникова, Ап. Григорьева, А. Н. Майкова, А. С. Суворина и др. - при этом нет ни слова о Ф. М. Достоевском, а его старший брат упомянут в процитированной ранее одной-единственной фразе: «В это время я написал одну только повесть “Бутузка", которая была напечатана в журнале М. М. Достоевского “Время"»".

Вместе с тем существует мемуарное свидетельство литератора П. В. Быкова (1844-1930) о его встрече в редакции «Времени» с Достоевскими, А. П. Милюковым и И. А. Саловым. Согласно автору этих воспоминаний, во время его прихода в редакцию сотрудники журнала читали «в гранках» «повесть» «Бутузка» в присутствии ее автора ${ }^{27}$. Эта «картина», позволяющая внести «подлинное дыхание эпохи и нагляднее представить себе жизнь редакции», была приведена В. С. Нечаевой в ее книге о журнале «Время» [Нечаева: 226], а С. В. Белов внес И. А. Салова в число лиц, окружавших Достоевского [Белов: 185].

Скептическое отношение к достоверности этого эпизода из воспоминаний Быкова высказывали А. С. Долинин ${ }^{28}$ и М. Д. Эльзон [Эльзон, 1987]. Последний, проанализировав архивные данные (РО ИРЛИ, ЦГАОР), указал, что в 1860-1864 гг. Быков учился в Харьковском университете и мог быть в Петербурге только краткими наездами, затем (до августа 1878 г.) жил в Харькове и Екатеринославе, где давал уроки и служил мелким чиновником. Быков только в августе 1878 г. «стал жителем столицы и вошел в литературную среду (в частности, выступал на похоронах Достоевского, был членом комиссии по организации похорон Тургенева)» [Эльзон, 1987: 173]. О пребывании Быкова в Петербурге до 1878 г. никаких сведений М. Д. Эльзон не обнаружил, а к свидетельствам мемуариста о его общении в начале 1860-х гг. 
с петербургскими литераторами призвал относиться с недоверием ${ }^{29}$. Категоричность суждения исследователя излишняя: он проигнорировал те места воспоминаний П. В. Быкова, из которых следует, что тот приезжал в Петербург во время летних каникул 1860-1861 гг. для работы в Публичной библиотеке, посещения редакций литературных журналов.

Встречался ли когда-либо сам Салов с Достоевскими - этот вопрос нуждается в дополнительном исследовании.

Переписка Достоевских и А. В. Зименко раскрывает практику редакционной работы в журналах «Время» и «Эпоха», позволяет выяснить некоторые обстоятельства публикации сочинения И. А. Салова «Бутузка» и роль в этом процессе его друга и посредника Зименко - одаренного поэта, секретаря нескольких известных периодических изданий, правую руку М. Н. Каткова в 1856-1858, 1861-1863 гг.

\section{ПРИМЕЧАНИЯ}

* Исследование выполнено при финансовой поддержке РФФИ, проект «Эпистолярное наследие Ф. М. Достоевского и его корреспондентов (1832-1867). Подготовка к публикации. Комментарии». № 17-34-01056а2.

1 См.: «Эпистолярное наследие Ф. М. Достоевского и его корреспондентов» [Электронный pecypc]. URL: http://philolog.petrsu.ru/fmdost/letters.htm. Отрывки из писем А. В. Зименко от 1 февраля, 17 мая 1865 г. публиковались: Достоевский Ф. М. Полное собрание сочинений: в 30 т. Л., 1985. Т. 28. Кн. 2. С. 523, 524. Далее - ПСС.

2 Письма А. В. Зименко к Ф. М. Достоевскому хранятся: РО ИРЛИ. Ф. 100. № 29719. Л. 1-7 об.

3 Отметим, что данное письмо М. М. Достоевского не сохранилось или еще не найдено. Из второго письма Зименко - от 1 февраля 1865 г. - следует, что он для доказательства своей правоты отправил письмо М. М. Достоевского в редакцию «Эпохи», но оговорил: «Только убпдительнпйше прошу Васъ посль возвратить мнюь его, потому что я желаль бы сохранить это письмо у себя какъ предсмертныя строки человпка, память котораго я свято чту и котораго я глубоко уважаль за ргдкія качества его ума и сердца». По всей вероятности, Достоевский выполнил просьбу и отослал письмо брата его владельцу.

4 Из воспоминаний И. А. Салова // Исторический Вестник. 1906. T. CVI. Октябрь. С. 179-180.

5 Исторический и современный адрес конторы, указанной Зименко для отправления корреспонденции Достоевского, уточнен в статье Б. Н. Тихомирова [Тихомиров: 75].

6 Записная тетрадь (1864-1865) / подгот. текстов Л. М. Розенблюм; коммент. К. Н. Полонской и С. С. Борщевского // Неизданный Достоевский: Записные книжки и тетради 1860-1881 г. М.: Наука, 1971. С. 201-242. (Литературное наследство; Т. 83.)

7 Достоевский Ф. М. Полн. собр. соч.: в 30 т. Л., 1985. Т. 28. Кн. 2. С. 567.

8 Венгеров С. А. Критико-биографический словарь русских писателей и ученых: в 6 т. СПб.: Семеновская Типо-литография (И. Ефрона), 1889-1904; Источники словаря русских писателей: в 4 т. / собр. С. А. Венгеров. СПб.: Тип. Имп. академии наук, 1900-1917; Геннади Г. Н. Справочный словарь о русских писателях и ученых, умерших в XVIII и XIX столетиях, и список русских книг с 1725 по 1825 г.: в 3 т. Берлин-Москва, 1876-1880, 1908; Русский биографический словарь: в 25 т. СПб.: Тип. И. Н. Скороходова, 1896-1918; Русские писатели. 1800-1917: биографический словарь / гл. ред. П. А. Николаев. М.: Большая российская энциклопедия, 1989-. 
9 Белов С. В. Ф. М. Достоевский и его окружение. Энциклопедический словарь: в 2 т. СПб.: Алетейя, 2001; Наседкин Н. Достоевский: энциклопедия. М.: Алгоритм, 2003.

10 См.: Заметки Нового Поэта о русской журналистике // Современник. 1851. Т. 27. С. 55.

11 Указатель имен // Некрасовский сборник. 1988. Т. IX. С. 204.

12 Журнал Министерства Народного Просвещения. 1848. Т. 59. Вып. 7-9. С. 104.

13 Под некоторыми из его стихов, кроме имени и фамилии, указана еще и местность написания произведения: «С. Грачевка».

14 Искра: сатирический журнал с карикатурами. 1863. № 1. С. 195.

15 Из записок А. В. Зименко // Русский Архив. 1883. № 1. С. 134.

16 Там же. С. 132-136.

17 РО ИРЛИ. Отд. пост. № 14239.

18 Салов И. А. Умчавшиеся годы (Из моих воспоминаний) // Русская Мысль. 1897. Кн. IX. C. 75.

19 Салов И. А. Умчавшиеся годы (Из моих воспоминаний) // Русская Мысль. 1897. Кн. VII. C. 1-27; Кн. VIII. С. 1-25; Кн. IX. С. 56-81; Кн. Х. С. 109-131. Из воспоминаний И. А. Салова // Исторический Вестник. 1906. T. CVI. Октябрь. С. 167-194. Ноябрь. С. 507-527.

20 Салов И. А. Умчавшиеся годы (Из моих воспоминаний) // Русская Мысль. 1897. Кн. IX. С. 77.

21 Из воспоминаний И. А. Салова // Исторический Вестник. 1906. T. CVI. Октябрь. С. 179.

22 Там же. С. 180.

23 В «Словаре псевдонимов...» подпись «Н. Салов» отмечена как псевдоним писателя в числе других: «Аг; Аз; Забудь меня!; Салов, А.; Салов, М.; Салов, H.; De mortuis aut bene aut nihil; S.» (Масанов И. Ф. Словарь псевдонимов русских писателей, ученых и общественных деятелей: в 4 т. М., 1960. Т. 4. C. 421. URL: http://feb-web.ru/feb/masanov/ man/08/man14806.htm). Другую точку зрения публикует Н. Ф. Хованский: «Вследствие типографской опечатки, рассказ этот явился с подписью “Н. Салов", также как позже другой рассказ “Аспид” - с подписью “М. Салов”» [Хованский: 164].

24 См.: Летопись жизни и творчества Ф. М. Достоевского: в 3 т. СПб., 1999. Т. 1. С. 494.

25 Достоевский Ф. М. Приходно-расходный журнал по изданию журналов «Время» и «Эпоха» // НИОР РГБ. Ф. 93.І.3.22.

26 Из воспоминаний И. А. Салова // Исторический Вестник. 1906. Т. CVI. Октябрь. С. 179-180.

27 Быков П. В. В редакции журнала «Время» братьев Достоевских. Первое знакомство с Саловым при чтении его рассказа. Дальнейшие встречи с ним // Быков П. В. Силуэты далекого прошлого. М., 1930. С. 56-64.

28 Достоевский Ф. М. Письма. М.; Л., 1928-1959. Т. ІІІ. С. 359.

29 Более того, в одной из своих работ, посвященных творчеству Н. С. Лескова, исследователь доказывает, что напечатанная Быковым неизвестная редакция «Жития одной бабы» - литературная мистификация, выполненная самим публикатором, а не Лесковым [Эльзон, 1988].

\section{СПИСОК ЛИТЕРАТУРЫ}

1. Белов С. В. Ф. М. Достоевский и его окружение: энциклопедический словарь: в 2 т. СПб.: Алетейя, 2001. - Т. 2. - 544 с.

2. Ден Т. П. Салов // История русской литературы: в 10 т. - М.; Л.: Изд-во АН СССР, 1956. - Т. 9: Литература 70-80-х годов. - Ч. 2. - С. 176-185. 
3. Кохно О. И. Раннее творчество И. А. Салова: (повесть «Бутузка») // Вестник Белорусского университета. Сер. 4: Филология, журналистика, педагогика, психология. Минск, 1987. — № 2. - С. 12-15.

4. Краснов Г. В. Салов Илья Александрович // Русские писатели. 1800-1917: биографический словарь. - М.: Большая российская энциклопедия, 2007. - Т. 5. - С. 461-464.

5. Ланский Л. Р. Достоевский в неизданной переписке современников (1837-1881) // Ф. М. Достоевский: Новые материалы и исследования. - М.: Наука, 1973. - С. 349-564. (Литературное наследство; Т. 86).

6. Нечаева В. С. Журнал М. М. и Ф. М. Достоевских «Время». 1861-1863. - М.: Наука, 1972. $-316 \mathrm{c}$.

7. Никонова Г. Л. И. А. Салов в полемике вокруг проблемы «нового человека» в русской литературе 70-х годов XIX века // Русская классическая литература и идеологическая борьба. - Ставрополь, 1983. - С. 43-55.

8. [Орнатская Т. И.] Рукою Достоевского / публ. Т. И. Орнатской // Достоевский: Материалы и исследования. - Л.: Наука, 1985. - Т. 6. - С. 3-31.

9. Перевалова Е. В. «Это был гуманный и заботливый хозяин типографии...»: М. Н. Катков как издатель // Текст. Книга. Книгоиздание. - 2018. - № 16. - C. 119-147. DOI: $10.17223 / 23062061 / 16 / 8$

10. Рожков В. П. Ранние произведения Салова (1854-1863) // Вопросы истории и теории литературы. - Челябинск, 1973. - С. 35-49.

11. Самочатова О. Я. Единство социального и нравственного в повести Тургенева «Муму» // Творчество И. С. Тургенева / под ред. Г. Б. Курляндской. - Курск: Курский гос. пед. институт, 1984. - С. 98-110.

12. Себелева А. В. Проза И. А. Салова и формирование русской беллетристики последней трети XIX века. - Нижневартовск: Изд-во Нижневарт. гуманит. ун-та, 2009. - 126 с.

13. Скабичевский А. М. История новейшей русской литературы (1848-1890). - СПб.: Тип. газеты «Новости», 1891. - 523 с.

14. Смирнов В. Б. И. А. Салов (1834-1902) // Русские писатели в Саратовском Поволжье / под ред. Е. И. Покусаева. - Саратов: Приволж. кн. изд-во, 1964. - С. 91-106 [Электронный ресурс]. — URL: http://library.sgu.ru/elcol/0699.htm (15.06.2018).

15. Т. [Пыпин А. Н.] Литературное обозрение: И. А. Салов. Суета мирская. Очерки и рассказы // Вестник Европы. - СПб., 1894. - Т. 168. - С. 880-885.

16. Тихомиров Б. Н. Петербургские адреса и адресаты Достоевского (К проблеме краеведческого комментирования адресных записей писателя) // Неизвестный Достоевский. - 2018. - № 3. - С. 56-105 [Электронный ресурс]. - URL: http://unknowndostoevsky.ru/files/redaktor_pdf/1541001296.pdf. DOI: 10.15393/j10.art.2018.3701

17. Фойницкий В. Н. Кугушев Г. В. // Русские писатели. 1800-1917: биографический словарь. - М.: Большая российская энциклопедия, 1994. - Т. 3. - С. 196.

18. Хованский Н. Ф. Очерки по истории г. Саратова и Саратовской губернии. - Саратов: Тип. Ищенко и Ко, 1884. - Вып. 1. - 235 с.

19. Эльзон М. Д. П. В. Быков и журнал «Время» // Достоевский: Материалы и исследования. - Л.: Наука, 1987. - Т. 7. - С. 172-173.

20. Эльзон М. Д. Существовала ли рукопись повести Н. С. Лескова «Амур в лапоточках»? // Русская литература. - 1988. - № 2. - С. 163-165.

21. Эльзон М. Д. Автора!!! // Нева. - 2002. - № 1. - С. 251-252.

Дата поступления в редакиию: 01.09.2018 
Irina S. Andrianova

Ph.D. in Philology,

Head of Web-laboratory of the Institute of Philology,

Petrozavodsk State University

(Petrozavodsk, Russian Federation)

yarysheva@yandex.ru

\section{From Editorial Correspondence Between "Vremya" and "Epokha": The Brothers Dostoevskys, Ardalion Zimenko, Iliya Salov"}

Acknowledgments. The reported study was funded by RFBR according to the research project no. № 17-34-01056a2.

Abstract. Letters are the texts in which an aesthetic aspect is not so important to the reader as the cognitive one. These letters need critical analysis and meaningful review, the identification of names and dates, the revelation and interpretation of the events described in them. The article studies a letter of one of F. M. Dostoevsky's correspondents, A. V. Zimenko. On December 19 1864 he wrote to the writer acting as the editor of the Journal "Epokha" with a request to pay him the rest of the fees for the short novel "Butuzka", published in the journal "Vremya" ("The Time") (1863, No. 2 and 3). Dostoevsky entered into correspondence with him. But the real author of "Butuzka" was writer I. A. Salov. The article presents archival and memoir evidence of professional life of Zimenko in "Russkiy Vestnik" ("The Russian Bulletin") and other journals, reconstructs the history of relationships of Zimenko and Salov. The appeal of Zimenko to Dostoevsky in the given letter should be considered as the request of the mediator Salov. The question of eventual meetings of Salov with the brothers Dostoevskys needs studying. The correspondence between the Dostoevskys and Zimenko reveals the editorial practice in the journals "Vremya" and "Epokha", allows us to find out some circumstances of the publication of Salov's work "Butuzka" and the role of his friend and mediator Zimenko in this process who was a gifted poet, secretary of several well-known periodicals, M. N. Katkov's assistant in 1856-1858, 1861-1863.

Keywords: Fedor Dostoevsky, Ardalion Zimenko, Ilya Salov, Pyotr Bykov, "Butuzka”, "Russkiy Vestnik", "Vremya”, "Epokha”, Mikhail Dostoevsky, scientific review

\section{REFERENCES}

1. Belov S. V. F. M. Dostoevskiy i ego okruzhenie: entsiklopedicheskiy slovar': $v 2$ tomakh [F. M. Dostoevsky and His Ambience: Encyclopedic Dictionary: in 2 Vols]. St. Petersburg, Aleteyya Publ., 2001, vol. 2. 544 p. (In Russ.)

2. Den T. P. Salov. In: Istoriya russkoy literatury: $v 10$ tomakh [History of Russian Literature: in 10 Vols]. Moscow, Leningrad, Academy of Sciences of the USSR Publ., 1956, vol. 9: Literature 70-80-ies. Part 2, pp. 176-185. (In Russ.)

3. Kokhno O. I. Early Works of I. A. Salov: (Povest' “Butuzka”). In: Vestnik Belorusskogo universiteta. Ser. 4: Filologiya, zhurnalistika, pedagogika, psikhologiya [Bulletin of the Belarusian State University. Ser. 4: Philology, Journalism, Pedagogy, Psychology]. Minsk, 1987, no. 2, pp. 12-15. (In Russ.)

4. Krasnov G. V. Salov Ilya Alexandrovich. In: Russkie pisateli. 1800-1917: biograficheskiy slovar' [Russian Writers. 1800-1917: Biographical Dictionary]. Moscow, Bol'shaya rossiyskaya entsiklopediya Publ., 2007, vol. 5, pp. 461-464. (In Russ.) 
5. Lanskiy L. R. Dostoevsky in the Unpublished Correspondence of Contemporaries (1837-1881). In: F. M. Dostoevskiy. Novye Materialy i issledovaniya [F. M. Dostoevsky. New Materials and Studies]. Moscow, Nauka Publ., 1973, pp. 349-564. (Ser. "Literary Heritage"; vol. 86). (In Russ.)

6. Nechaeva V. S. Zhurnal M. M. i F. M. Dostoevskikh «Vremya». 1861-1863 [The Journal of Mikhail and Fedor Dostoevsky "Vremya". 1861-1863]. Moscow, Nauka Publ., 1972. 316 p. (In Russ.)

7. Nikonova G. L. I. A. Salov in the Dispute on the Problem of a "New Man" in Russian Literature of the 1870s. In: Russkaya klassicheskaya literatura i ideologicheskaya bor'ba [Russian Classical Literature and Ideological Struggle]. Stavropol, 1983, pp. 43-55. (In Russ.)

8. Ornatskaya T. I. Dostoevsky's Handwriting. In: Dostoevskiy: Materialy i issledovaniya [Dostoevsky: Materials and Researches]. Leningrad, Nauka Publ., 1985, vol. 6, pp. 3-31. (In Russ.)

9. Perevalova E. V. "It Was a Humane and Caring Owner of a Printing House...”: Mikhail Katkov as a Publisher. In: Tekst. Kniga. Knigoizdanie [Text. Book. Publishing], 2018, no. 16, pp. 119-147. DOI: 10.17223/23062061/16/8 (In Russ.)

10. Rozhkov V. P. Early Works of Salov (1854-1863). In: Voprosy istorii i teorii literatury [Issues of History and Theory of Literature]. Chelyabinsk, 1973, pp. 35-49. (In Russ.)

11. Samochatova O. Ya. The Unity of the Social and the Moral in the povest' "Mumu" by Turgenev. In: Tvorchestvo I. S. Turgeneva [Works of I. S. Turgenev]. Kursk, Kursk State Pedagogical University Publ., 1984, pp. 98-110. (In Russ.)

12. Sebeleva A. V. Proza I. A. Salova i formirovanie russkoy belletristiki posledney treti XIX veka [The Prose of I. A. Salov and the Genesis of Russian Fiction of the Last Third of the 19th Century]. Nizhnevartovsk, Nizhnevartovsk State University for Humanities Publ., 2009. 126 p. (In Russ.)

13. Skabichevskiy A. M. Istoriya noveyshey russkoy literatury (1848-1890) [History of Contemporary Russian Literature (1848-1890)]. St. Petersburg, Tipografiya gazety «Novosti» Publ., 1891. 523 p. (In Russ.)

14. Smirnov V. B. I. A. Salov (1834-1902). In: Russkie pisateli v Saratovskom Povolzh'e [Russian Writers in the Saratov Region on the Volga River]. Saratov, Privolzhskoe knizhnoe izdatel'stvo Publ., 1964, pp. 91-106. Available at: http://library.sgu.ru/elcol/0699.htm (accessed on June 15, 2018). (In Russ.)

15. Pypin A. N. Literary Review: I. A. Salov. Worldly Vanity. Essays and Stories. In: Vestnik Evropy. St. Petersburg, 1894, vol. 168, pp. 880-885. (In Russ.)

16. Tikhomirov B. N. Dostoevsky's Addresses and Addressees in Petersburg (On the Problem of Regional Commentary of Address Records of the Writer). In: Neizvestnyy Dostoevskiy [The Unknown Dostoevsky], 2018, no. 3, pp. 56-105. Available at: http://unknown-dostoevsky.ru/ files/redaktor_pdf/1541001296.pdf. DOI: 10.15393/j10.art.2018.3701 (In Russ.)

17. Foynitskiy V. N. Kugushev G. V. In: Russkie pisateli. 1800-1917: biograficheskiy slovar' [Russian Writers. 1800-1917: Biographical Dictionary]. Moscow, Bol'shaya rossiyskaya entsiklopediya Publ., 1994, vol. 3, p. 196. (In Russ.)

18. Khovanskiy N. F. Ocherki po istorii goroda Saratova i Saratovskoy gubernii [Essays on the History of the City of Saratov and the Saratov Province]. Saratov, Tipografiya Ishchenko i Ko Publ., 1884, issue 1. 235 p. (In Russ.)

19. El'zon M. D. P. V. Bykov and the Journal "Vremya”. In: Dostoevskiy: Materialy i issledovaniya [Dostoevsky: Materials and Researches]. Leningrad, Nauka Publ., 1987, vol. 7, pp. 172-173. (In Russ.)

20. El'zon M. D. Was Did a Manuscript of N. S. Leskov's Povest' "Amour in Bast Shoes" exist? In: Russkaya literatura, 1988, no. 2, pp. 163-165. (In Russ.)

21. El'zon M. D. The Author!!! In: Neva, 2002, no. 1, pp. 251-252. (In Russ.) 